\title{
Human heart sarcolemmal sheath antibodies in children with non-suppurative sequelae of group A streptococcal infections: a follow up study
}

\author{
H A Majeed, A M Yousof, J Pokorny, R Bicova, G Bahr, K Behbahani, J Rotta*
}

\begin{abstract}
The kinetics of the human heart sarcolemmal sheath antibody were studied in children with acute rheumatic fever who had no carditis, children with acute rheumatic fever who had carditis and developed rheumatic heart disease, and in children with acute poststreptococcal glomerulonephritis. The children with rheumatic fever and those who developed valvular heart disease were given continuous secondary antistreptococcal prophylaxis. The titre of antibody at onset was significantly higher than that of the controls in children with acute rheumatic fever and carditis and in children with acute poststreptococcal nephritis. The difference in the antibody titre between children with rheumatic fever who had no carditis and controls was not statistically significant. After a mean follow up of three years, however, a high titre was only maintained in children with rheumatic fever who developed valvular heart disease.
\end{abstract}

Heart reactive antibodies were produced in rabbits immunised by group A streptococci; these antibodies bound to the sarcolemmal sheath of the cardiac myofibres, skeletal muscle, and the smooth muscles of the vessel walls. ${ }^{1-3}$ By fluorescent absorption studies Kaplan identified two cross reactive systems in the cell wall of the streptococci: one was type specific whereas the other was universal to all serotypes. ${ }^{1-3}$ These heart reactive antibodies were different from those detected in patients with postcardiotomy syndrome, Chagas' disease, Dressler's syndrome, and in patients with rejected cardiac transplants. ${ }^{1-3}$ The heart reactive antibodies in patients with rejected cardiac transplants were absorbed only by cardiac tissue but not the streptococcal antigen, showing that such antibodies were not induced by streptococci. $^{1-3}$ Zabriskie et al detected heart reactive antibodies in patients with acute rheumatic fever, acute poststreptococcal glomerulonephritis, and in non-complicated streptococcal infections; the antibody was fourfold higher in patients with rheumatic fever. ${ }^{4}$ The titre declined slowly over a period of two to three years. These heart reactive antibodies were absorbed by the streptococcal membrane, however, thus differentiating them from those demonstrated by Kaplan, which were absorbed by the cell wall of the streptococci. Furthermore, the heart reactive antibodies described by Zabriskie $e t$ al in patients with acute rheumatic fever were also different from those produced in rabbits immunised by the streptococcal membrane. ${ }^{4}$ Van de Rijn et al purified heart reactive antibodies from patients with acute rheumatic fever and showed that they bound strongly to the human heart sarcolemmal sheath (HHSS), poorly to skeletal muscles, and did not bind to the smooth muscles of the vessel walls. ${ }^{5}$ To the best of our knowledge no studies have attempted to explore the kinetics of these antibodies after their purification by van de Rijn $e t a l .^{5}$ These antibodies may have a role in the pathogenesis of acute rheumatic fever. In this paper we report our findings on the kinetics of these antibodies in children with acute rheumatic fever who had no carditis, children with rheumatic fever and carditis who developed rheumatic heart disease, and children with glomerulonephritis.

\section{Patients and methods}

PATIENTS

Four groups of subjects were studied. Group 1 comprised 15 children with an initial attack of acute rheumatic polyarthritis; group 2 consisted of 15 children with an initial attack of rheumatic fever which progressed to rheumatic heart disease. Two other groups of children, matched for age and sex with the two groups with rheumatic fever and rheumatic heart disease, were included in this study. A group of 13 children with acute glomerulonephritis (group 3) and a group of 27 normal children (group 4) served as controls (see table 1). All children were followed up for three or more years.

Groups 1 and 2 were treated monthly with benzathine penicillin G. Children of group 1, 2, and 3 were bled within 48 hours of admission to hospital and on subsequent follow up visits. All serum samples were separated and stored at $-20^{\circ} \mathrm{C}$ until tested. Of the 15 children with rheumatic fever and who developed rheumatic heart disease, 11 had mitral incompetence, seven had aortic incompetence, the valvular lesions were single or in combination. The diagnoses of rheumatic fever and glomerulonephritis were based on internationally accepted criteria. ${ }^{67}$

\section{METHODS}

The heart reactive antigen was prepared using the technique described by Van de Rijn et al. ${ }^{5}$ Briefly, human heart was removed five hours after death, cleaned from fat, ground for five minutes at $4^{\circ} \mathrm{C}$, and centrifuged at $14000 \mathrm{~g}$ for 30 minutes. The sediment was washed three times with saline and autolysis performed by 
incubating one volume of the sediment with 100 volumes of distilled water for 24 hours at $4^{\circ} \mathrm{C}$. This was repeated three times, and the sediment was then suspended in $0.05 \mathrm{M}$ TRIS- $\mathrm{HCl}$ buffer (pH 7.5) containing $1 \mathrm{mM} \mathrm{Mg}^{2+}$ and treated with $1 \mathrm{mg}$ RNase $/ \mathrm{ml}$ and $1 \mathrm{mg} \mathrm{DNase} / \mathrm{ml}$ at $37^{\circ} \mathrm{C}$ for three hours. A few drops of chloroform were added as antibacterial agent, and the suspension was then centrifuged at $14000 \mathrm{~g}$ for 30 minutes. The sediment was washed three times under the same conditions and lyophilised. The sheath antigen was further extracted with $1 \%$ sodium dodecyl sulphate at $100^{\circ} \mathrm{C}$ in a water bath for three minutes, as described by Dale and Beachey. ${ }^{8}$ The sediment was collected after centrifuging at $18000 \mathrm{~g}$ for 30 minutes, and this will be referred to as the HHSS antigen. The HHSS was ultrasonically disintegrated at $23 \mathrm{kH}$ (Soniprep 150, MSE, England) in a concentration of $1 \mathrm{mg} / \mathrm{ml}$ for $2 \times 10$ minutes and then applied to microtitre plates as antigens.

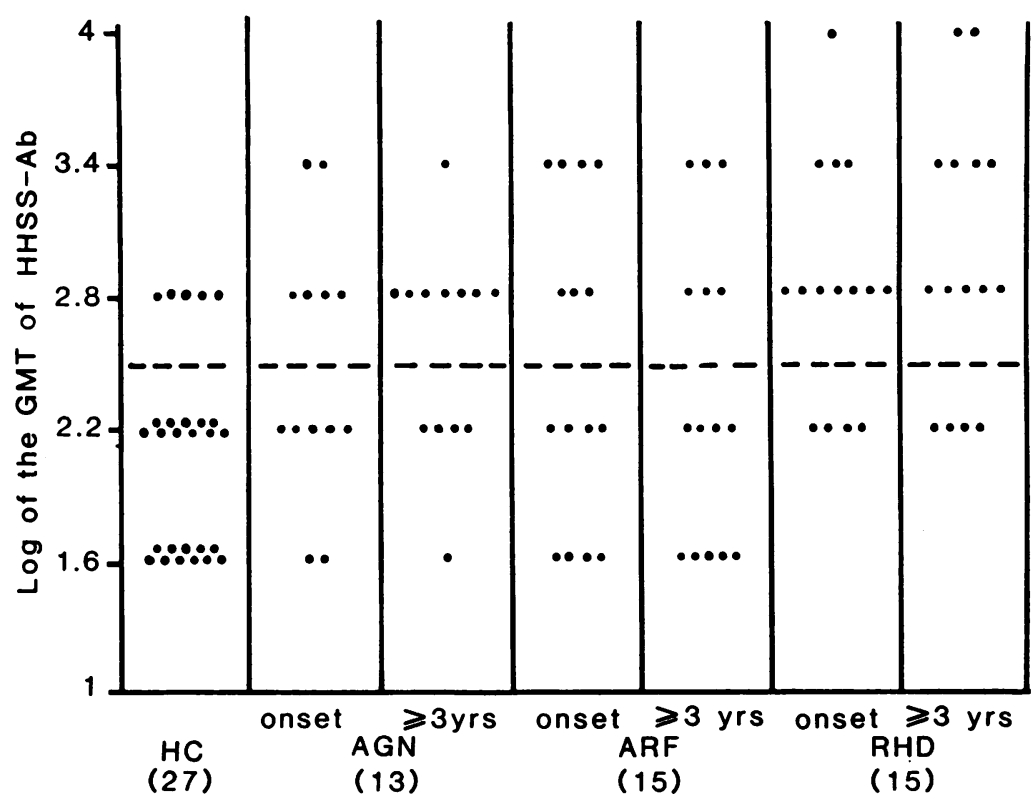

Distribution of human heart sarcolemmal sheath antibody titres in the groups at onset and after three or more years. The dashed line shows the upper limit of the normal value.

$G M T=$ geometric mean titre; $H H S S-A b=$ human heart sarcolemmal sheath antibody;

$H C=$ healthy controls; $A G N=$ acute glomerulonephritis; $A R F=$ acute rheumatic fever; $R H D=$ rheumatic heart disease.

Table 1 Demongraphic data of the four study groups

\begin{tabular}{|c|c|c|c|c|c|c|c|}
\hline \multirow[t]{2}{*}{ Diagnosis } & \multirow[t]{2}{*}{$n$} & \multicolumn{2}{|c|}{ Age (years) } & \multicolumn{2}{|l|}{ Sex } & \multicolumn{2}{|c|}{ Follow up } \\
\hline & & Range & Mean & Male & Female & Range & Mean \\
\hline $\begin{array}{l}\text { Acute rheumatic fever } \\
\text { Rheumatic heart disease } \\
\text { Acute glomerulonephritis } \\
\text { Normal }\end{array}$ & $\begin{array}{l}15 \\
15 \\
13 \\
27\end{array}$ & $\begin{array}{l}5-12 \\
5-16 \\
3-11 \\
4-12\end{array}$ & $\begin{array}{l}9 \\
9 \cdot 5 \\
6 \cdot 5 \\
8\end{array}$ & $\begin{array}{r}8 \\
12 \\
7 \\
16\end{array}$ & $\begin{array}{r}7 \\
3 \\
6 \\
11\end{array}$ & $\begin{array}{l}2 \cdot 4-5 \cdot 3 \\
2-5 \\
2-4 \cdot 3 \\
-\end{array}$ & $\begin{array}{l}3 \cdot 8 \\
3 \cdot 8 \\
3 \\
-\end{array}$ \\
\hline
\end{tabular}

Table 2 Log of the geometric mean titre of the antibodies at onset and at $\geqslant 3$ years

\begin{tabular}{|c|c|c|c|c|c|c|}
\hline \multirow[t]{2}{*}{ Group (n) } & \multicolumn{3}{|l|}{ At onset } & \multicolumn{3}{|c|}{$A t \geqslant 3$ years } \\
\hline & $H H S S^{*}$ & $A S O T^{*}$ & $A n t i-D N A_{s e} B$ & HHSS & ASOT & $A n t i-D N A_{s e} B$ \\
\hline $\begin{array}{l}\text { RHD* }^{*}(15) \\
\text { ARF* }^{*}(15) \\
\text { AGN* (13) }^{*} \\
\text { Controls (27) }\end{array}$ & $\begin{array}{l}2 \cdot 83 \\
2 \cdot 44 \\
2 \cdot 48 \\
2 \cdot 1\end{array}$ & $\begin{array}{l}2 \cdot 53 \\
2 \cdot 56 \\
2 \cdot 66 \\
2 \cdot 04\end{array}$ & $\begin{array}{l}2 \cdot 7 \\
2 \cdot 75 \\
2 \cdot 75 \\
2 \cdot 34\end{array}$ & $\begin{array}{l}2 \cdot 97 \\
2 \cdot 36 \\
2 \cdot 62 \\
-\end{array}$ & $\begin{array}{l}2 \cdot 38 \\
2 \cdot 26 \\
2 \cdot 57 \\
-\end{array}$ & $\begin{array}{l}2 \cdot 38 \\
2 \cdot 35 \\
2 \cdot 67 \\
-\end{array}$ \\
\hline
\end{tabular}

${ }^{*}$ HHSS = human heart sarcolemmal sheath; ASOT=antistreptolysin O titre; RHD=rheumatic heart disease; $A R F=$ acute rheumatic fever; $A G N=$ acute glomerulonephritis.
Indirect microsolid phase radioimmunoassay was carried out on disposable microtitre plates (Cooke, England/United States), using a sandwich technique. ${ }^{9}$ Antigen was fixed at a concentration of $0.5 \mu \mathrm{g} / 50 \mu \mathrm{l}$ phosphate buffered saline per well; the serum samples were diluted in phosphate buffered saline containing $1 \%$ bovine serum albumin. Specific antibodies were detected by protein A (Pharmacia, Sweden) labelled with iodine-125 (Amersham, England). Dosimetry was carried out with a gammacounter (Crystal II multidetector, RIA system, Packard-nberra, United States). Results were calculated as counts per minute and compared with negative and positive serum standards. Positivity was expressed in dilution titres. Each specimen was tested in fourfold dilution ranging from 40 to 40960 . The antistreptolysin $O$ and anti-DNA $\mathrm{se}_{\mathrm{se}} \mathrm{B}$ antibody titres were determined as described previously. ${ }^{10} 11$

Statistical analysis for differences in distribution was by the Mann-Whitney U rank test.

\section{Results}

The upper limit of the normal titre of HHSS antibody was taken as the titre exceeded by no more than $20 \%$ of the normal controls. The log of the geometric mean titre of the upper limit of normal was thus taken as $2 \cdot 4$ (see figure). Table 1 shows the basic data of the four groups. Table 2 shows the logs of the geometric mean titre of the antibodies in the four groups at the onset and after three or more years. Table 3 shows the statistical differences of the antistreptolysin $\mathrm{O}$ titre and anti-DNAse B antibodies in the four groups at onset. Table 4 shows the statistical differences of the HHSS antibody in the four groups at onset and at three or more years.

The figure shows the distribution of HHSS antibody titres in the three groups at onset and at three or more years and also in the controls.

Table 3 Statistical differences in the logs of the geometric mean titre of antistreptolysin $O$ titre and anti-DNA $B$ at onset

\begin{tabular}{lll}
\hline Groups & \multicolumn{2}{l}{$p$ Value at onset } \\
\cline { 2 - 3 } & ASOT & Anti-DNA $B$ \\
\hline RHD $v$ control & 0.0001 & 0.01 \\
ARF $v$ control & 0.0001 & 0.003 \\
AGN $v$ control & 0.0001 & 0.02 \\
\hline
\end{tabular}

For abbreviations see table 2 .

Table 4 Statistical differences in the logs of the geometric mean titre of human heart sarcolemmal sheath antibodies at onset and at $\geqslant 3$ years

\begin{tabular}{lll}
\hline Groupst & $p$ value \\
\cline { 2 - 3 } & At onset & At $\geqslant 3$ years \\
\hline RHD $v$ controls & $0 \cdot 002^{*}$ & - \\
ARF $v$ controls & $0 \cdot 1$ & - \\
AGN $v$ controls & $0 \cdot 05^{*}$ & - \\
RHD $v$ ARF & $0 \cdot 19$ & $0 \cdot 03^{*}$ \\
RHD $v$ AGN & $0 \cdot 14$ & $0 \cdot 2$ \\
AGN $v$ ARF & $1 \cdot 0$ & $0 \cdot 3$
\end{tabular}

* Significant difference.

†For abbreviations see table 2. 


\section{Discussion}

Evidence has accumulated over the past 30 years suggesting that the cross reactive antigens in both heart and streptococci are membrane associated. Through the purification of the heart reactive antibodies (HHSS antibodies) described by Zabriskie et $a l^{4}$ the cross reactive streptococcal membrane antigen was shown to be composed of four polypeptide chains with a molecular weight ranging between 22000 and 32000 daltons. $^{5}$

Data from our study show that the titres of the HHSS antibody at onset were significantly higher in patients with rheumatic heart disease than in controls (tables 2 and 4), but the titres were not significantly different between the group with rheumatic heart disease and the other two groups. At three or more years, however, the titres of the HHSS antibody were significantly higher in the group with rheumatic heart disease than the group with acute rheumatic fever (tables 2 and 4). In fact the titre in patients with rheumatic heart disease had increased between onset and $\geqslant 3$ years, whereas it decreased in the group with rheumatic fever. This in an important finding as both groups were receiving continuous antistreptococcal secondary prophylaxis, and showed that a persistently high titre of the HHSS antibody was only maintained in patients with rheumatic fever who developed rheumatic heart disease. This behaviour is similar to that of the group A specific polysaccharide antibody. ${ }^{12} 13$

The titre of the HHSS antibody in the group with glomerulonephritis was higher than that in the group with rheumatic fever at the onset, though the difference was not statistically significant. This is a surprising finding and not in agreement with the results of Zabriskie et $a l^{4}$ and van de Rijn et al. ${ }^{5}$ The titre of the HHSS antibody at three or more years was markedly higher in the group with glomerulonephritis than in the group with rheumatic fever (table 2), but the difference was not statistically significant. For interpretation of these findings, however, it should be stressed that the groups with rheumatic fever and rheumatic heart disease were receiving continuous antistreptococcal prophylaxis, whereas the group with glomerulonephritis was not. This is shown by the changes in the titres of antistreptolysin $\mathrm{O}$ and anti-DNA ${ }_{\text {se }} B$ antibodies. The titres of these two antibodies at the onset were significantly higher in the three groups than in the controls (tables 2 and 3). At three or more years after the onset the titres of these antibodies in groups with rheumatic fever and rheumatic heart disease were less than those at the onset (tables 2 and 3 ).
On the other hand, the changes of the titres of these two antibodies in the group with glomerulonephritis were minimal; furthermore, the titres at three or more years were higher than those in the groups with rheumatic fever and rheumatic heart disease. Possibly, in the group with glomerulonephritis, who were not receiving prophylaxis, streptococcal infections might have contributed to the rise of the HHSS antibody titre. This may be similar to the situation in which streptococcal infections which resulted in recurrences of rheumatic fever were reported to cause a rise in the HHSS antibody titres. ${ }^{4}$

In conclusion, the finding that a high titre of the HHSS antibody in patients with acute rheumatic fever was only maintained in those who developed valvular heart disease is significant as this antibody binds to the HHSS. Further studies with longer periods of follow up would certainly be worthwhile.

Supported by a grant MK015 from the University of Kuwait.

1 Kaplan M H. Rheumatic fever, rheumatic heart disease and the streptococcal connection: the role of streptococcal
antigens cross-reactive with heart tissue. Rev Infect Dis antigens cross-react

2 Kaplan $M$ H, Meyeserian $M$. An immunological crossreaction between group $A$ streptococci cells and human heart. Lancet 1962; i: 706-10.

3 Kaplan M H. Immunological relation of streptococcal and tissue antigens. Properties of an antigen in certain strains of group A streptococci exhibiting an immunological crossreaction with human heart tissue. $\mathcal{f}$ Immunol 1963; 90 . 595-606.

4 Zabriskie J B, Hsu K C, Seegal B C. Heart-reactive antibody associated with rheumatic fever: characterization and associated with rheumatic fever: characterization and

5 Van de Rijn I, Zabriskie J B, McCarty M. Group A streptococcal antigens cross-reactive with myocardium. Purification of heart reactive antibody and isolation and characterization of the streptococcal antigen. $\mathcal{F} \operatorname{Exp} \mathrm{Med}$ 1977; 146: 579-99.

6 Ad hoc committee to revise the Jones criteria (modified) of the council on rheumatic fever and congenital heart disease, of the American Heart Association: Jones criteria (revised) for guidance in the diagnosis of rheumatic fever. Circulation 1983; 69: 204A.

7 Lange K, Wassermann E, Slobody L B. The significance of serum complement levels for the diagnosis and prognosis of acute and subacute glomerulonephritis and lupus erythematosus disseminatus. Ann Intern Med 1960; 53: 636-46.

8 Dale J B, Beachey E H. Protective antigenic determinant of streptococcal M protein shared with sarcolemmal membrane protein of human heart. $\mathcal{F}$ Exp Med 1982; 156: 1165-76.

9 Trlifajova J, Pakorny J, Nemecek V, Ryba M. Radioimmuno assay for antibodies in varicella zoster virus serology. $\mathcal{F}$ Hyg Epidemiol Microbiol Immunol 1979; 23: 332-9.

10 Rotta J, Facklam R. Manual of microbiological diagnostic methods for streptococcal infections and their sequelae. Geneva: WHO, 1980: 39-43. (Document WHO/BAC/80.1.)

11 Rotta J, Facklam R. Manual of microbiological diagnostic methods for streptococcal infections and their sequelae. Geneva: methods for streptococcal infections and their sequelae.

12 Dudding B A, Ayoub E M. Persistence of group A streptococcal carbohydrate antibodies in patients with chronic coccal carbohydrate antibodies in patients with chron

13 Appleton R S, Victoriea B E, Tamer D, Ayoub E M Specificity of persistence of antibody to the streptococcal group A carbohydrate in rheumatic valvular heart disease. J Lab Clin Med 1985; 105: 114-9. 